Marquette University

e-Publications@Marquette

English Faculty Research and Publications

English, Department of

$1-1-2001$

\title{
Reading the Emotions of Salome: Sympathy for the Devil or Fear and Loathing
}

Diane Hoeveler

Marquette University, diane.hoeveler@marquette.edu

Published Version. Prism(s): Essays in Romanticism, Vol. 9 (2001): 87-108. C) 2001 International Conference on Romanticism. Used With Permission. 


\section{A Reading of the Emotions of Salome: Sympathy for the Devil, or Fear and Loathing}

Diane Long Hoeveler

n October 1876 Gustave Flaubert was engaged in writing what would become perhaps his most well-known and successful piece of short fiction, "A Simple Heart." This narrative dissects the life of an innocent servant woman, ironically named Felicity, who transfers her love and spiritual devotion from object to object until she finally settles, after life's many disappointments, on a stuffed and tattered parrot as the incarnation of her god of love. The horror of Flaubert's story can be located in his dark and cynical portrayal of love and spiritual devotion as a form of fetishism, a mad scramble for apparently random substitute objects to compensate for the original wound in the psyche, the primordial fall we all supposedly make from a sense of original wholeness and self-sufficiency within the individual ego into psychic fragmentation. Felicity's pathetic stuffed parrot functions as a fetish, while fetishism-or the displacement of the sexual object by a metonymic substitute-stands in Flaubert as the originating source of both love and religious worship. ${ }^{1}$ 
Although often considered the exact opposite of a "romantic" work, Flaubert's tale is important as an example of what I would call the "postromantic residue," the reaction against romanticism that lingered in nineteenth-century literary culture, on the continent as well as in Britain. But whether one was a romantic or a realist, one began to resort to depicting representations of Salome in nineteenth-century cultural products. The Salome trope reemerged in this particular period just as bourgeois culture sought to codify its values, power, and identity, and the differential uses of the figure made by female and male artists can tell us important things about late romantic culture. For instance, just as Flaubert was writing "A Simple Heart" he was engaged in meditating on the biblical legend of Salome and her mother Herodias, her stepfather Herod, and her nemesis John the Baptist that resulted in his short story "Herodias," published along with "A Simple Heart."

Flaubert does not know why he was drawn to thinking about the Salome story at just this time, but he went on in a letter to a friend to observe: "The story of Salome and Herodias, as I understand it, has no relation to religion. What captivates me in this, is the official face of Herod and the ferocious face of Herodias, a type of Cleopatra and de Maintenon." ${ }^{2}$ This disclaimer is significant, not simply because Flaubert was currently engaged in writing a story about the fetishistic origins of the religious impulse, but because he seized on Salome and her mother and then denied that they had anything to do with religion.

The Salome trope has everything to do with religion and specifically with religion's complicity with political and social constructions of middle-class behaviors and emotions. The almost obsessive recurrence of the Salome representation in the nineteenth century in Britain, France, Germany, Russia, and America was caused by religiously motivated dread and anxiety about the role and representation of emotionally excessive, vengeful, or passionate women in those societies. The fixation on Salome was no random historical event, just as it was no accident that Flaubert found himself thinking about her legend just as he was writing "A Simple Heart." Salome became, through a confluence of paintings, poems, stories, and dramas, the ultimate fetishistic woman of late romantic consciousness. Always depicted in league with her powerful mother, Salome and Herodias became the very embodiments of what can be seen as the residual traces of the matriarchal fantasy. In a narrative that is ultimately about a power struggle between two men-one 
representing religious and spiritual power and one embodying secular authority - the woman suddenly inserts herself, like a bad dream, like a reminder of an earlier society in which women had both religious and political power and could wield that power for their own ends. The fetishistic residue that clings to the whirling, veiled dancing body of Salome is the imagined power of women to influence men's religious and political decisions through their sexuality, their bodies. And this power is perceived by men to be fearful and potent. In fact, the reminder of this power is so threatening that it must be contained, safely painted and dramatized in such a way that men and male power structures trace the representation of the powerful woman out of existence. At the same time, female artists were presenting a very different Salome, an innocent victim, a pawn used in a brutal barter system controlled by men. And finally there is the question of the sheer excess of emotion and artistic interest invested in the figure. Why did Salome elicit such hatred or, conversely, such sympathy? How and why did her representation intersect with the era's attempts to define, codify, and control appropriate bourgeois emotions?

In attempting to understand the legend of Salome, however, one encounters literally thousands of pieces of cultural data. For instance, "Maurice Kraft has listed 2,789 French poets who have written about Salome" (ctd. in Severi 458). Obviously the challenge in analyzing such a pervasive representation of a woman is to select one's materials carefully. This essay will examine the most well-known representations of Salome, as well as the more obscure story by Amelia Edwards, "The Story of Salome" (1872). By contrasting the better-known representations of the figure as constructed by men to the more sympathetic depiction by a female writer, I hope to suggest that the evolution of attitudes towards the emotions was gendered and developed in radically different and competing contexts. For women artists, Salome was a victim because of her religious difference, but for male artists, Salome was a victimizer because of those differences, all of which had to be eradicated before society would be safe from her pernicious and potentially anarchic influence.

It is necessary to begin, however, by briefly describing the biblical depictions of Salome and her mother that occur in two of the Gospels, then to summarize some of the major artistic presentations of Salome throughout the next centuries, and finally to focus on the contrast 
between Amelia Edwards's victimized and sympathetic Salome and Oscar Wilde's curious portrayal of her alongside Aubrey Beardley's famous illustrations for the drama. The first biblical description of Salome occurs in Matthew's Gospel (14:1-13). In this version Herod is afraid of the power of John, specifically John's standing with the people. Herod is persuaded to decapitate John not because he wants to but because the nameless daughter of his second wife has requested it as her reward for dancing at his birthday celebration. What is most significant about this version, however, is that Salome is presented as a dutiful daughter who takes her orders from her mother, not her stepfather. She is in league, in other words, with the matriarchy, not the patriarchy. Salome appears to have no interest in John or what he has been saying about her mother. The mother, however, does. She wants John silenced because he has been telling everyone that she is an adulteress and an incestuously tainted one at that. Herodias had married Herod, her first husband's half-brother, who was himself already married. Whereas this sort of behavior may be commonplace now, it was not an ordinary occurrence at this time. And specifically, it was a violation of Mosaic law. But Salome, Herodias, and Herod are pagans; they are not Jews. The religious attempt to control human sexuality is what is at issue in John's rantings. Herod stands accused and impotent before John, but the woman Herodias acts. What she wants exterminated is the voice of the prophet, the religious voice that reminds civil authorities that they must adhere to spiritual values and beliefs if they are to be respected as rulers by the people they are leading.

In the second version of the same story-this time in the Gospel of Mark (6:17-28) — we learn that Herod actually considers John a holy man and holds him in awe. The intensity of the relationship between the two men is emphasized, while once again Herodias and her daughter are outsiders and the slandered victims of the holy man's tongue. The major change in the story is that in this version the again unnamed daughter is the one who asks for John's head "on a dish." In the first version it was the mother who added that pretty touch.

These two well-known biblical texts take on a new light, though, when we compare them to the one contemporary historical version we have of the same event. The Jewish historian Josephus tells us that it was Herod and Herod alone who ordered the killing of John because he feared John's influence to incite rebellion by the people. Josephus is also 
the source for Salome's name, but he is quite explicit about how and why John was killed and neither Salome nor her mother had anything to do with the execution (Josephus 398). ${ }^{3}$ Is this simply a case of cherchez la femme, blaming the nearest woman for the trouble, or is something else at stake in the biblical versions? It would, I think, be safe to conclude that the biblical texts had a different purpose and intended audience than those motivating the Jewish historian Josephus. The biblical texts are establishing the tenets and beliefs of a new religion, whereas the historical document is merely attempting to present the unvamished and rather ordinary facts. The Gospel writers clearly thought they had a reason for blaming the murder of John on two women, but what was it? Why did they have an investment in inserting a young girl and her mother into the political action and giving them both so much power over two men, one a civil leader and one a powerful and respected religious prophet?

The subtext of both biblical versions of the story would appear to center on the anxiety about the unregulated sexuality of the womenboth the mother and her daughter. The ideology operating in the biblical texts goes something like this. Christianity, that is, a new and reformed version of Judaism, is a superior religion because it promises to find a way to control women who interfere in the masculine domains of religion and politics. Such women, lawless and lustful, deceitful and seductive, will eventually be brought to heel and punished. In the biblical versions John is the scapegoat for the mother's crimes, while the mother and daughter-in their evil cabal of sexuality and treachery-remind men that civil society and religious worship will continue to be impossible if such women have real power. The story of Salome and her mother is actually the story of the potential for evil female influence on the state and on religion, and such influence, whether wielded covertly or overtly, can only produce chaos. The New Testament Gospel stories promise a new and better society presided over by a religion in which evil pagan women and their lawless sexuality will be contained and disciplined. But the Salome legend as it stands in the two Gospels is incomplete, and thus we have many visual depictions of the story up to this point-usually Salome dancing or Salome holding John's head as her trophy. ${ }^{4}$ The narrative, in other words, is left open for the patriarchy to complete, and that it does when it concludes the story by punishing Salome, meting out to her the torture and death she deserves for 
inappropriately meddling in the two domains women have been traditionally prohibited from entering - politics and religion. Salome and her mother must be replaced by Jesus and his mother as models of the new social and political order. And it is in that transition from matriarchy to patriarchy, with women safely inscribed in their maternal role, that we see Salome's meaning most clearly.

The representation of Salome virtually disappears for the next four centuries, but she reappears in the fourth century and becomes a favorite topic with authors of Roman decadent literature. What is interesting here is that she resurfaces just as a political empire is crumbling, and again she is associated with the chaos caused by political and religious upheaval. She vanishes again from view until the Crusades, when she suddenly reappears and again in league with her mother. The two women are depicted everywhere- on stained glass windows, on the walls of churches throughout France, and most famously on the wall of the Cathedral of Rouens, where Salome is painted as walking on her hands, which appears to suggest a particularly lustful way of dancing. When next we see Salome it is the Renaissance and suddenly she is depicted as quiet and dignified. Giotto, Ghirlandaio, Titian, Luin, Andrea del Sarto, and Fra Filippo Lippi all paint her as a lovely and harmless woman, and I would suggest that this is because an era of strong male religious and political leaders had nothing to fear from a stage mother and a teenage girl with a penchant for dancing. ${ }^{5}$

But then as if waking up from a long sleep Salome reappears in Germany in 1842 in Heinrich Heine's Atta Troll and there she becomes the relatively uncomplicated representation of beauty without morality. She no longer appears to have any political or religious meaning, but instead stands as the incarnation of the cruel indifference to be found in women. Strongly influenced by both Heine and Flaubert's short story, as well as by the paintings of Gustave Moreau, Joris-Karl Huysman's novel Against Nature was published in 1884 in France. It is best remembered today as a handbook on decadent beliefs but also contained several lengthy and influential meditations on the meaning and representation of Salome as found in Moreau's two most famous paintings of her: The Dance of Salome and The Apparition. Moreau did over seventy sketches of Salome during this period, revealing that he was somewhat obsessed with the figure and considered her a particularly appropriate object lesson for his age. Moreau's two most famous paintings were exhibited 
in Paris in 1876 and served to influence Huysmans, Mallarme, and Flaubert, who in their turn influenced Oscar Wilde to compose his drama on the subject.

In the painting The Dance of Salome we are presented with a variety of sexual symbols, most prominently the pinkish-white lotus which represents sensual pleasure. On Salome's left arm is a bracelet adorned with a large eye, the Ujat of the ancient Egyptians, source of the magic fluid. Opposite her is a black panther, a symbol of lust. Behind a bare-breasted girl playing a lute, Herodias stands holding a fan made of peacock feathers, another symbol of lust. Overlooking Herod's throne is a statue of the great goddess Diana of Ephesus with her double row of breasts, an image of fecundity. She is flanked by two statues of Ahriman, the Persian god of evil. Finally, at the far left of the painting is a large intaglio engraved with an image of the sphinx holding in its claws the body of a male victim. The painting strives, in other words, to capture an atmosphere of mystery and sensuality, an era outside of history or historical accuracy. This is a psychic snapshot of what the universe would look like if it were presided over by a woman, a male dream of what history would look like if women unleashed their sexual power to control and dominate men. ${ }^{6}$

The Apparition, exhibited alongside the first painting, moves the scene to the innermost recesses of a mosque before the highly ornate niche housing a statue of the Buddha. The asymmetrical layout of the painting features the full figure of Salome with outstretched hand balanced against the severed and radiant head of John the Baptist, who can be seen by no one but Salome. She is standing as if called by the floating head to account for her crime. A pool of blood oozes onto the floor, but the painting does not have a morbid or even a particularly realistic feel to it. What is most dominant is the fact that the male gaze itself-as embodied in John's floating and decapitated head-is inscribed in the painting. It is that accusing and controlling male gaze that ultimately has the power to fix, discipline, and punish the female sexuality that Salome so visibly flaunts in this work. ${ }^{7}$ This painting stands as an early visual depiction of what became the emphasis in the nineteenth century on completing the Salome narrative-punishing the woman for her crime-rather than fixing on the earlier biblical portion of the narrative- the dance and decapitation.

Simonides' famous remark that poetry is vocal painting and that painting is silent poetry is demonstrated in the French depictions of 
Salome that begin to proliferate during this period. There are clear connections between the paintings of and poetry about her that began to appear with such a vengeance in post-romantic Europe. Both visual and verbal artists were reacting to each other's visions in a way that perhaps had not been done since the Renaissance focused its attention on the virgin and child representation. Why would Salome reappear at precisely this historical moment and with such a ferocity of attention? It is possible to propose some explanations, but what is important about these nineteenth-century depictions is that they make clear that the penultimate stage of the Salome narrative was finally being written.

It is necessary at this point, however, to explain the connection between the Salome trope and the romantic and post-romantic construction of the emotions. The early part of the era was dominated by theorists of subjectivity (Hume, Rousseau, Adam Smith, et al.) who sought to define the newly dominant middle-class subject as male, rational, white, bourgeois, heterosexual, and Christian. Unfortunately, there were persons who did not share these characteristics. These persons were female, emotionally excessive and given to irrational actions, in addition to sometimes being colored or "dark," class indeterminate, and nonChristian. Such traits, of course, exactly characterized Salome, and so it was the culture's ideological task to discipline and punish her, as well as ultimately to exterminate her so that the world would again be safe for the dominant and normative person, the rational male. What dominates nineteenth-century depictions of Salome, however, is the male artist's desperate attempts to read her vindictive behavior by understanding her emotional motivations. Her distant expression, her cool and calculated demeanor, her ruthlessness, these were all unacceptable emotions in a woman, and, in fact, revealed a particularly dangerous woman, one who was conducting herself like a man.

It is important at this point to explore more generally the concept of the emotions. As Theodore Sarbin notes, what we label as the emotions today is "really a variegated collection of situated actions which serve to establish moral identity roles, (as distinct from social roles.)" Sarbin goes on to claim: "On this formulation, grief, anger, jealousy, and exultation for example are the names of roles played out in the service of maintaining or enhancing one's moral identity. They are patterned actions in the same sense that greetings and farewells are patterned actions. But the patterns of conduct of identity roles are intimately connected to values. 
It is in support of one's values that the actor makes judgments about the conduct of self and other" (87). In other words, emotions "are thus like miniature dramas which we learn to perform from childhood onward and which define our moral self-image" (Dodd 153).

Another definition of the emotions is provided by Robert Solomon, who has claimed: "Our emotions are not only projections; they are our projects. They are not only directed towards intentional subjects; they are laden with intentions to act. Emotions are concerned not only with the way the world is, but with the way the world ought to be. Every emotion is also a personal ideology, a projection into the future, and a system of hopes and desires, expectations and commitments, intentions and strategies for changing our world" (212). Finally, someone like Pierre Bourdieu, in his Outline, places the question of the emotions into what he defines as a "habitus." This concept refers to "'systems of durable, transposable dispositions' produced in a group or community by a particular environment-for instance, 'the material conditions of existence characteristic of a class condition"' (72; qtd. in Dodd 153, footnote). These dispositions produce consistent patterns of behavior that are not simply "the product of obedience to rules, nor though, objectively adapted to their goals." Instead, they involve "a conscious aiming at ends or an express mastery of the operations necessary to attain them." Habitus as a concept does not rely on social type because it examines a wider and more diverse range of factors in analyzing any action.

What these theories of the emotions reveal is that subjectivity, more popularly known as personality, could be read and understood if one could recognize in another person a consistent pattern of actions motivated by a readily identified repertoire of emotions. To be understood and accepted by their society, women found it in their best interests to be as calm, rational, and unemotional as possible. The ideal of the "rational woman" was espoused, for instance, by Mary Wollstonecraft, and her plan for an educational system for women was largely based on creating women as much in man's image as possible. The literature of the period was suffused with depictions of the struggle that was occurring over defining and codifying appropriately gendered behavior. Byron's feminized heroes were as socially unacceptable as were Wollstonecraft's heroines, and the romantic period gradually moved to a middle ground on the issue of bourgeois control of the emotions as well as gendered displays. ${ }^{8}$ Salome reemerges at just this point as an ideological object lesson 
to middle-class women: conform or pay the price. Her excessive and performative gender display is publicly denounced as she is forced to renounce first, her religion (in the nineteenth century she is presented as a Jewess) and then her sexual identity, and finally her life.

But to turn now to the Salome trope as represented by a female writer. In a little-known short story that has survived because it has been collected as an example of the female-authored "ghost" story, Amelia Edwards's "The Story of Salome" presents a sympathetic and victimized Salome living in the Jewish ghetto of Venice.' The exotic and dark beauty of this young woman has brought her to the attention of Coventry Tournour, a British aristocrat, who persuades his friend, Harcourt Blunt, to accompany him on a trip to the shop owned by Salome's father. Working behind the counter in her father's Oriental goods store, Salome is the embodiment herself of the Orient, dark, brooding, melancholy, projecting "unconscious dignity, perfect nobleness and refinement" (65). In a scene that is reminiscent of Byron's "Don Juan," Salome informs the suitor that she is selling Greek jewelry, not Turkish goods, before she is quickly dismissed by her father, a jealous guardian of his daughter's marketability. Harcourt spends a year traveling in the Far East but finds himself drawn back to Venice to find the "beautiful Jewess": "Somehow I could not get Tournour and his love affairs out of my head" (66). The woman, as Eve Sedgwick has noted, plays the role of exchange object, mediator between the two men in a homosocial dyad. ${ }^{10}$ But more importantly for this story, the figure of Salome mediates between two conflicting cultures and religions.

Harcourt fruitlessly searches for Salome, unable even to locate her father or the business, until one night he finds himself in the Jewish cemetery, "the ghetto of the dead!" (68; her italics). His thoughts as he strolls among the graves are distinctly literary:

I fell into one of those wandering trains of thought in which the real and unreal succeed each other as capriciously as in a dream. I remembered how Goethe here conceived his vertebral theory of the skullhow Byron, too lame to walk, kept his horse on the Lido, and here rode daily to and fro-how Shelley loved the wild solitude of the place, wrote of it in "Julian and Maddalo," listened, perhaps from this very spot, to the mad-house bell on the island of San Giorgio.... [I wondered] if Othello had walked here with Desdemona-if Shylock 
was buried yonder, and Leah whom he loved "when he was a bachelor." (68-69)

What is interesting about this passage is the way emotions are stimulated by literary nostalgia, reverie, and melancholy. It is as if Harcourt himself had buried his Leah here, and that, of course, is precisely what we learn has occurred. Life mirrors art or art mirrors life, and we learn how to display our emotions and even what emotions to have by reading literature. It is interesting, too, that the passage moves progressively toward the Jewish father and then ultimately settles on the dead Jewish fiancé.

After more wandering among the tombstones and lengthy ruminations on mortality, Harcourt suddenly sees Salome, "pale and worn as from some deep and wasting grief, but more beautiful, if that could be, than ever," sitting beside a grave (69). She refuses to speak and quickly disappears, so Harcourt decides to try to identify the writing on the tomb's inscription, thinking that she must be visiting her father's grave. He visits the tomb two more times, each time seeing the silent and remote Salome, and on the third visit she finally speaks, making a request of him: “'A Christian soul lies there,' she said, 'laid in earth without one Christian prayer-with Hebrew rites-in a Hebrew sanctuary. Will you, stranger, perform an act of piety towards the dead?...Read one prayer over this grave; trace a cross upon this stone" (75). Thinking that perhaps her father had secretly converted to Christianity, Harcourt finally receives the translation of the tomb's inscription, only to learn that it is Salome herself who is buried there, dead at the age of twenty-one.

Aghast, confused, Harcourt visits a local rabbi who informs him that Salome did profess "secret doubts" (78) about Judaism before she suddenly died, and the reader is left with the uneasy sensation that the young and healthy Salome may have been murdered by her own father, who could not accept a daughter who would convert or marry against his wishes. This Salome is no seductress or femme fatale; she is instead a victim of her father's jealous mania and his religion's intolerance. When Harcourt thinks about Salome, his description reveals her victimized and sympathetic situation: "I knew now why she had appeared to me clothed with such unearthly beauty. I understood now that look of dumb entreaty in her eyes-that tone of strange remoteness in her voice. The sweet soul could not rest amid the dust of its kinsfolk" (79). This Salome 
has contained her emotions to an enviable degree. She is stoic in the face of even the most atrocious crime and injustice. As Edwards presents her, Salome represents the woman as a powerless pawn in the marriage market, a bartered exchange object who is not allowed to control any of her life's choices, not even her religion. If Salome is punished in this story, she does not deserve the death sentence she received.

But the story is considerably different when Salome haunts the pages of a drama written by a male artist. What is even more revealing is that the nineteenth-century male artist centered his attention not just on Salome's traditional crime, but also on her punishment-her execution-which we know was absent in both the historical record and the Gospel accounts. Male artists - or to be more precise, Oscar Wildetook it upon himself to act for the patriarchy and execute Salome at the conclusion of his drama. Why? And why, we might further want to ask, did he choose to costume himself as Salome and pose with a facsimile of a man's decapitated head on a charger? Several critics have noted that Salome is probably Wilde's most intense self-portrait (Shewan 126)." These behaviors reveal a persistent pattern, not simply of misogyny, which is how the drama is usually read, but of an inability to accept difference as anything but a threat that must be exterminated. It would appear that it is the tendency of all logocentric discourse systems-particularly literature - to trace differences-whether they be sexual or political or religious - out of existence. When the late nineteenthcentury male artist retells the Salome story, the heroine of the text progressively disappears, first as a pagan or Jew, then as a woman, and finally as a political revolutionary in league with the matriarchy. We can understand this as one manifestation of the power of the male gaze to fix the woman as an object and then dehumanize, pathologize, or finally exterminate her. First she dies and is mummified in the German literary texts, laid out on a table and disinfected with the phallic lotus flower of Huysmans, but even more uncanny is Salome's treatment by Wilde. ${ }^{12}$ In his vision and in the illustrations of Beardsley, she finds herself replaced by men pretending to be women. The first hint we have that the real purpose of Wilde's drama is to deny sexual difference can be found in the eccentric and brilliant illustrations done for the text by Aubrey Beardsley.

In examining Beardsley's title page to Wilde's drama, one is immediately confronted with a piece so shocking that one gazes on it 
against one's inclinations. And that is the point of the illustration-it solicits our gaze. It is an invitation to voyeurism. It proclaims its intention to shock by presenting us with a very demonic hermaphroditic figure, genitals exposed, standing between two phallic candles and worshiped by an equally hermaphroditic and mocking angel at the bottom of the page. Most uncanny about the perverted nature of the illustration is the use of eyes on both the nipples and the navel. The sense of being looked at from those originating sources of life, those residues of female biological power, constitutes the paranoia animating this spectacle. The title page, however, also proclaims the goal of the drama and subverts it at the same time. If the dream of the play is the elimination of women, then why present a phallic woman on the title page? The title page presents in a bold and brazen manner the fear animating Wilde and his society. Beardsley depicts here the phallic woman because it is her visage, her body, her power that Salome ultimately represents and that Wilde fears and destroys by the end of his drama. In his revised version of this title page, Beardsley edited his own vision for publication and made the figure's sexuality safer. ${ }^{13}$

In the first plate for the play, called "The Woman in the Moon," the face in the moon is Wilde's. Beardsley is here gently mocking Wilde's desire not simply to be a woman, but to usurp the traditionally feminine power of the external world as represented in the moon. Karen Horney has labeled this desire on the part of men "womb envy," but what we see in Wilde is a more pernicious desire, a need to deny women not only their power over the external world, the processes of birth and generation, but also their power to invoke love and loyalty in men. The two human figures looking at the moon, usually read as a man and a woman, are in fact two men-the page and the young Syrian. We learn later in the play that the page loves the young Syrian, who rejects him for a hopeless love of Salome. The young Syrian's suicide haunts the drama, as does the love that the page has for his fallen male comrade. In the plate where the page is mourning for the young Syrian we can see their identities more clearly, and note that both are posed in front of an extremely stylized portrayal of nature-the frozen tree and the vibrantly tangled rose bush. The moon, implies Wilde, presides over a world that frustrates men's devotion to one another by inserting a large, mutable, and ultimately false female force between them. The moon as woman or woman as the moon dominates the drama and in depicting Wilde as the face in 
the moon, trying to usurp a traditional female power, Beardsley both exposes and gently mocks the futility of Wilde's desire.

But Salome or the representation of woman in this drama would also appear to embody in her person the world of nature as opposed to the world of court society. She is the embodiment of irrational emotions poised against John's reason and restraint. And finally she is the physical, the body, the dance standing in opposition to the word, the logos, the disembodied voice of John. All of these characteristics can only make Salome expendable in the eyes of Wilde, for the emotions and the body, as well as the natural realm, are for Wilde threatening and destructive powers, forces that must be first controlled and then exterminated so that what he recognizes as society-that is, the triumph of the masculine and the artificial-can occur.

In looking at the next plates - all of which center on the mirroring nature of John and Salome-we arrive at the fantasy animating Wilde's play. In his vision the sexual difference between men and women will be obliterated, and thus we have virtually identical bodies and faces in several of the plates. In "John and Salome" it is Salome who dons massive rosethorns in her hair and whose nipples and navel are once again depicted as having eyes. This imagery connects her to the phallic woman of the title page, just as John's flowing hair connects him to the page of the first plate. But this is a drama that centers on an act of decapitation. The nightmare animating the work centers precisely on the vulnerability of the male head, the seat of the organs of vision and understanding, the power that resides in reason. The fear that the head can be severed from the body and taken into the hands and control of a woman is the anxiety that motivates this legend. Traditional Freudian tropes read the fear of decapitation as a fear of castration, and certainly in this drama we can detect an anxiety about the destructive power of woman that borders on the pathological. But setting aside Freudian claims, we can conclude that the power struggle here between Salome-the power of the bodyand John-the power of the mind-is all about the struggle to control and discipline the emotions of a woman. In the plate "The Dancer's Reward," Salome grips John's hair and stares at an identical version of her own face in the decapitated head. We have another version of this in the plate entitled "The Climax." Here Salome is demanding her kiss from John's head, and this is perhaps the most perverse moment in the play: "I will bite your lips with my teeth as one bites a ripe fruit." This 
had traditionally constituted the conclusion of the narrative, but Wilde revises the story and has Herod, in disgust, order Salome's death: "Kill that woman." In killing the woman, Wilde brings the biblical narratives to their logical conclusion.

Wilde's play has explored the power of interpretation and narrative, while it centers on a few key scenes of specularity, of looking and being looked at. The play aligns the field of vision with Salome, the body and the power of sexual desire, in contrast to the verbal field, which is aligned with John, the embodiment of the immaterial and the rational. Salome represents the body's claims over John, who embodies the power of the verbal. The duel between the two of them is ultimately a duel to determine which forces will control human history, political systems, and power structures. When Herod states at the end of the drama, "Kill that woman," we know that we have been led to the logical endpoint of patriarchal discourse systems. The patriarchy, recognizing the ultimately uncontrollable desires and power of woman, has to act to exterminate her. But the woman has never been real to the patriarchy, which has always been compelled to read her as a sign in the text for blankness, absence, or a variety of self-projected fantasies: woman as virgin, woman as whore, woman as moon, woman as cesspool. Herod can kill Salome the individual woman, but he cannot kill the dance of gender that animates history and will simply give rise to a new representation of woman based on the needs of the next generation. ${ }^{14}$ Thus Salome appears again in the poetry of Yeats and Laforgue and in the 1905 opera by Richard Strauss.

We might recall here Wilde's words from the Preface to The Picture of Dorian Gray: "All art is at once surface and symbol." What we see in Wilde's drama is a fixation on a series of displaced images of the powerful and ultimately fearsome mother-the moon and her avatars-the real power of the external world, the goddess of Nature presiding over the ontological reality that men experience. Wilde's drama is not simply misogynist, which it is. More frighteningly, it presents a dream-text in which women, the embodiment of evil, sexual depravity, and Nature are finally eradicated by a powerful father-figure who asserts his ultimate political power by realizing that his real enemy is not John, the masculine voice of reason, but the woman, the essence of difference, the Other. ${ }^{15} \mathrm{~A}$ dream of homoerotic bonding suffuses Wilde's text as it does Beardsley's illustrations. For Beardsley, women are really men, or rather 
men are really women. The Wilde drama and its illustrations stand as a unified textual universe presenting a fetishized portrayal of women as part-objects, residual reminders of the fact that they once were part of the prior and stronger male body. The dream that animates Wilde's drama is the belief that women will ultimately disappear and that men can once again inhabit an all-male universe of beautiful soldiers, powerful politicians, and all-wise religious prophets living in harmony with one another.

To summarize a position put forward in the well-known essay "Castration or Decapitation?" Helene Cixous begins by asking her reader, "What is woman for man?"(480). She answers by way of stating that "if man operates under the threat of castration, if masculinity is culturally ordered by the castration complex, then women operate under castration's displacement, decapitation" (481). The culturally imposed silence on women is simply the opposite of the stereotype that has traditionally plagued woman-that she is an endless chatterer. For Cixous, the "Absolute Woman, in Culture," is the "hysteric," the woman who by being "prey to masculinity" actually makes possible her Other, the father. But Cixous saw this woman as characterized by other qualities-namely tactility, disgorging, and mourning for the property relations that circulate in her economy. She is not haunted by a quest for origins like the man but instead takes up the challenge of loss to go on living (479-90).

It should be clear from the above brief synopsis that Salome and John the Baptist, archetypal figures of gendered warfare, stand as the two poles of decapitation and castration that Western society has proffered as possible alternatives for the sexes. Frozen in a tableau vivant, the two exist as veritable gender clichés, inhabiting history as a living museum of horrors. In the story of John and Salome we confront again the realization that castration or decapitation stand as the fate of the sexes. It is our worst cultural nightmare that the phallus/power can be severed; the tongue can be silenced. Both sexes fear that they actually do inhabit a world where their most basic identifications can be turned against them, where they are powerless to protect or speak for themselves. When Salome kisses the red lips of the decapitated head of John, we know ourselves to be in the presence of what is euphemistically called a borderline personality. The head, the love object, tropes that partial object that we know is the essence of fetishism. The decapitation is a castration, and 
both Salome and John exist here as the very embodiments of what Cixous proffered as her vision of the sexes in Western culture.

Recent feminist critics want to claim that "the revolutionary potential of female desire is the theme of Wilde's Salome," but all of the interpretations along these lines posit female desire as an oppositional, critical or revolutionary force and tend to align desire with the preverbal body, and with the forces of political resistance that have been suppressed or repressed by society (Marcus 8-9). But this does not seem to be what is at stake in the Salome story. It is more likely that the recurrence of the Salome legend illustrates the power of the patriarchy to shape narratives and perceptions, both of oneself and of others. There was a historical Salome just as there was a historical John the Baptist. But what is important in their story is that a variety of human minds have shaped their narrative for a variety of reasons and those reasons emerge from the need to ensure a society and religion in which women and their emotions function as complements rather than as threats to men and male power structures.

Salome staring at the decapitated head of John, the symbolic embodiment of both the masculine mind and its voice, stands as an embodiment of the most threatening moment to the patriarchy. That moment calls into question any fixed relation between mind and body, between the world of thought and spirit and the world of the senses. When Salome seizes John's head she is demanding the power to control the masculine mind and voice. She is demanding to be like a man in her control of her emotions and to have the power that a man has in both political and religious institutions. And that is why the narrative could not be allowed to stand as if concluded at that point. Salome cannot be allowed to hold the head, the masculine mind, the voice of the prophet and kiss it and claim it as her own. She has to be punished and that nineteenth-century male artists and writers did. In an era that recognized all too well the vulnerabilities plaguing European political and religious systems, the woman had to be punished.

Briefly, we can now examine the history of the Salome trope in the twentieth century. The first film version of the story was done in 1918 with Theda Bara in the leading role. And an even more famous silent film was made of the subject in 1922, starring the Russian actress Alta Nazimova. The Italian director Carmelo Bene made a successful adaptation of Wilde's drama for the film in 1972 and in 1979 Lindsay Kemp 
staged an all-male drag version of the Wilde play for the stage. For Kemp, who played Salome himself, Salome's story was a parable of the gay artist, a psychomachia of Wilde's own tragedy, as well as a study of the isolation of the homosexual from society. Ken Russell's 1987 film, Salome's Last Dance, is a similar sort of drag performance of Wilde's drama staged as a play within a play with Wilde sitting in the audience as a spectator-voyeur. Salome turns out to be played by a boy and the film forces its viewers to confront the homosocial bonding that suffuses both society and art. ${ }^{16}$

Finally, there is the 1953 Hollywood biopic Salome, called at the time of its production a "madly misconceived" film adaptation of the story, starring Rita Hayworth, Charles Laughton, and Stewart Granger. In this version Salome is a secret convert to Christianity who dances in order to save John from the designs of her evil mother's revenge. What is interesting here is that the power of logocentric discourse has reached its final logical endpoint. The Wilde drama and the subsequent drag versions of it work to eliminate the sexual difference of women, but this particular Hollywood version, like the Edwards short story, works to eliminate the religious difference as well. Here Salome is not a pagan or even a Jew, as she was depicted in a number of German works of the pre-Nazi and Nazi era. In this ultimate capitalistic retelling of the narrative, all of the important differences are removed and Salome becomes a Christian and a tool of the patriarchy, poised and actively working against her mother, the last trace of an earlier and once powerful matriarchal religion and society.

In 1854 Pope Pius IX declared the Virgin Mary to have been the only woman born without original sin. As we have seen, the counter-cult of Salome arose in just this decade and almost as if in opposition to the cult of Mary that was growing in France, Germany, Italy, and Spain. My point in juxtaposing the Pope's decree and the rise and virulence of the Salome story is to make one final point: women have traditionally been represented by patriarchal systems in opposition to each other, in either a virgin/whore dichotomy or in a mother/daughter dyad representing generation and potential fertility. The Salome story arose at just this time because both traditional religion and political systems felt themselves to be under siege by changes they were uncertain they could navigate. Hence Mary reappears as a virtual goddess whose power is at the disposal of the church, while Salome reappears as the cause of all the trouble, the 
whore of Babylon, the scapegoat. The cry that goes up in the nineteenth century, the Woman will save us, is always coupled in the history of patriarchal representation with the belief and fear that the woman will destroy us. We know from the Jewish historian Josephus that the historical Salome married and had children. She appears to have been an ordinary woman and, to recall Flaubert, we might even be tempted to say that perhaps she had a simple heart. So why has she taken on a life beyond her historical identity; why has she been constructed as a femme fatale, a witch, a seductress, a whore, and a castrator of a good and holy man? All of those questions take us back to the originating one: why do patriarchal representations construct women the way they do? What purpose is served politically, religiously, socially? I would conclude by noting that such stories allow the patriarchy to close ranks against the woman and to trace women and their emotions as different, as Other, out of existence.

Notes

1. The parrot as a love object tropes that partial object that we know is the essence of fetishism, but its tattered form allows us also to read it as an abject fetus. As Julia Kristeva notes, "When a subject confronts the factitiousness of object relations, when he stands at the place of the want that founds it, the fetish becomes a life preserver, temporary and slippery, but nonetheless indispensable" (Powers of Horror: An Essay on Abjection [PH], trans. Leon S. Roudiez [New York: Columbia UP, 1982] 37). The most extensive discussion of the fetish, including a full theoretical analysis of both Marx's and Freud's contributions to the idea, can be found in William Petz's three-part article "The Problem of the Fetish, I, II, IIIa," in Res 9 (1985); 13 (1987); 16 (1988). Freud observes that "Psychoanalysis... has shown the importance, as regards the choice of a fetish, of a coprophilic pleasure in smelling which has disappeared owing to repression. Both the feet and the hair are objects with a strong smell which have been exalted into fetishes after the olfactory sensation has become unpleasurable and been abandoned." See his Three Essays on the Theory of Sexuality (Standard Edition 7:155). Freud's most detailed discussion of fetishism occurs in his essay "Fetishism" (1927): "When I now disclose that the fetish is a penis-substitute I shall certainly arouse disappointment; so I hasten to add that it is not a substitute for any chance penis, but for a particular quite special penis that has been extremely important in early childhood but was afterwards lost" (SE 21:203). In his "History of an Infantile Neurosis" Freud establishes the symmetry between the terms "faeces," "baby," and "penis," noting that all of these objects "can be separated from one's own body" and therefore are symbols of "lack" (SE 17:84). I do not want to 
privilege Freud or Freudian theory (one lives these days in fear of being accused of political incorrectness), but I cannot help noticing the obvious parallels to Salome's bare feet, her swirling hair, and her status as a child of Herodias.

2. The letter is quoted and the background to Flaubert's composition of "Herodias" is discussed in Bram Dijkstra, Idols of Perversity: Fantasies of Feminine Evil in Fin-de-Siecle Culture (New York: Oxford UP, 1986) 380-82.

3. The role of Josephus in propagating the Salome narrative, as well as other early biblical commentators, can be found in Helen Grace Zagona, The Legend of Salome and the Principle of Art for Art's Sake (Geneva: Droz, 1960) ch.l.

4. Dijkstra's discussion of the paintings of Salome is thorough and impressive (380-401), but can be usefully supplemented by Françoise Meltzer, Salome and the Dance of Writing: Portraits of Mimesis (Chicago: U of Chicago P, 1987).

5. The history of the Salome representation as the object of the male gaze is nicely summarized in Brad Bucknell, “On 'Seeing' Salome,” ELH 60 (1993) 503-26.

6. The best discussion of Moreau's Dance of Salome is in Meltzer 66 passim.

7. The most typical discussion of Moreau's Apparition examines the painting in relation to the description of it in Joris-Karl Huysmans's A Rebours [Against Nature]: "She had become, as it were, the symbolic incarnation of undying Lust, the Goddess of immortal Hysteria, the accursed Beauty exalted above all other beauties by the catalepsy that hardens her flesh and steels her muscles, the monstrous Beast, indifferent, irresponsible, insensible, poisoning, like Helen of ancient myth, everything that approaches her, everything that sees her, everything that she touches" (trans. Robert Baldrick 66).

8. The issue of romanticism's construction of gender has been extensively treated in a number of recent critical studies: Diane Long Hoeveler, Romantic Androgyny (University Park: Penn State P, 1990); Anne Mellor, Romanticism and Gender (New York: Routledge, 1993);Tim Fulford, Romanticism and Masculinity (New York: St. Martin's, 1999). For a discussion of gender constructions during the latter part of the century, see Linda Dowling, "The Decadent and the New Woman in the 1890s," Nineteenth-Century Fiction 33 (1979): 434-453.

\section{Amelia Edwards (1831-92) was the author of three well-known travelbooks} about her trips to Egypt. Her "Story of Salome" was published in 1872 and reprinted in her collection of stories, A Night on the Borders of the Black Forest (1874). The story was most recently reprinted in Victorian Ghost Stories by Eminent Women Writers, ed. Richard Dalby (New York: Carroll \& Graf, 1988) 64-80. All quotations will be from this edition, with page numbers in parentheses in the text. 
10. When a woman is positioned in such a way that two men are actually enthralled with each other and using the blank screen of a woman as the mediating point, then we know that we are witnessing what Eve Sedgwick has labeled "homosocial desire." See her Between Men: English Literature and Male Homosocial Desire (New York: Columbia UP, 1985).

\section{Also see Richard Ellman's biography of Wilde, Oscar Wilde (New York:} Vintage, 1988), which first reproduced the photograph of Wilde posed as Salome, as well as Ellman's Eminent Domain: Yeats among Wilde, Joyce, Pound, Eliot and Auden (New York: 1967), 3-24; and Golden Codgers (London: 1973), 39-59. The photograph, which has been the subject of a fair amount of debate as to its authenticity, has also been helpfully discussed by Elaine Showalter in her Sexual Anarchy: Gender and Culture at the Fin de Siecle (New York: Viking, 1990) 152; 156-57.

\section{J-K Huysman's A Rebours [Against Nature], presents this description of Des} Esseintes's reaction to Moreau's Salome Dancing Before Herod (1876): "Perhaps, too, in arming his enigmatic goddess with the revered lotus-blossom, the painter had been thinking of the dancer, the mortal woman, the soiled vessel, ultimate cause of every sin and every crime; perhaps he had remembered the sepulchral rites of ancient Egypt, the solemn ceremonies of embalmment, when practitioners and priests lay out the dead woman's body on a slab of jasper, then with curved needles extract her brains through the nostrils, her entrails through an opening made in the left side, and finally, before gilding her nails and her teeth, before anointing the corpse with oil and spices, insert into her sexual parts to purify them, the chaste petals of the divine flower" (66-7).

\section{Aubrey Beardsley's illustrations for Wilde's play Salome (New York: Dover,} 1967) are available in many sources. Wilde's drama was written originally in French, as a tribute to the decadent tradition in which Salome herself played such a major role. He later claimed that it had been translated into English by Lord Alfred Douglas. Douglas himself later admitted that the translation had been done by Wilde. The most concise reproduction of the pertinent images in relation to the play can be found in Jeffrey Wallen, "Illustrating Salome: Perverting the Text?" Word \& Image 8 (1992): 124-32. As Wallen points out, "Beardsley's drawings, by revealing the 'hidden parts' of the sexual object, follow the path of sexual curiosity, rather than that of sublimation, art, and civilization. To this extent, the drawings offer a 'de-aestheticization' of the verbal text, and a giving way to the 'pleasure in looking,' to 'scopophilia'” (125).

14. For a discussion of the persistence of the image of Salome as represented by Wilde, see Mario Praz, The Romantic Agony, trans. Angus Davidson (London: Oxford UP, 1970) 317: "In Germany, it has held the boards for a longer period than any other English play, including the plays of Shakespeare. It has been translated into Czech, Dutch, Greek, Hungarian, Polish, Russian, Catalan, Swedish, and even Yiddish....The Salomes of Flaubert, of Moreau, Laforgue, and Mallarme are known only to students of literature and connoisseurs, but the Salome of the genial comedian Wilde is known to all the world." 
15. See the very sophisticated study of the drama's relation to the Beardsley illustrations in Elliot Gilbert, “Tumult of Images': Wilde, Beardsley, and Salome," in Victorian Studies 26 (1983), 133-59.

16. A discussion of the films can be found in Severi, 462, and Showaltern.

\section{Works Cited}

Baldick, Robert. The Life of Joris Huysmans. Oxford: Oxford UP, 1955.

Bourdieu, Pierre. Outline of a Theory of Practice. Trans. Richard Nice. Cambridge: Cambridge UP, 1977.

Cixous, Hélène. “Castration or Decapitation?” Trans. Annette Kuhn. In Contemporary

Literary Criticism. 2nd ed. Ed. Robert Con Davis and Ronald Schleifer. New York: Longman, 1989.

Dodd, William. "Destined Livery?: Character and Person in Shakespeare," Shakespeare Survey 51 (1998), 147-58.

Edwards, Amelia. "Story of Salome." Victorian Ghost Stories by Eminent Women Writers.

Ed. Richard Dalby. New York: Carroll \& Graf, 1988.

Huysmans, Joris-Karl. A Rebours (Against Nature). Trans. Robert Baldrick. Baltimore: Penguin, 1959.

Josephus. The Works of Flavius Josephus: The Jewish Wars. Trans. G. A. Williamson.

Harmondsworth: Penguin, 1981.

Marcus, Jane. Art and Anger. Columbus: Ohio State U P, 1988.

Sarbin, Theodore. "Emotions as Situated Actions." Emotions in Ideal Human

Development. Ed. I. Cirillo and S. Wapner. Hillsdale, NJ. 1989.

Severi, Rita. "Oscar Wilde, La Femme Fatale and the Salome Myth." Proceedings of the 10th Congress of the International Comparative Literature Association. Vol 2. Ed.

Claudio Guillen. New York: Garland, 1985.

Shewan, Rodney. "The Artist and the Dancer in Three Symbolist Salomes." Bucknell

Review. Ed. Mark Neuman and Michael Payne. Lewisburg: Bucknell UP, 1986.

Solomon, Robert. The Passions. South Bend: Notre Dame 1983.

Wilde, Oscar. Plays, Prose Writings and Poems. New York: Everymans. 1956. 